\title{
Kazakistan Süt Üretimi ve Süt Endüstrisi
}

\author{
Firuza Koboyeva $^{1 *}$, Nuray Güzeler ${ }^{1}$ iD \\ ${ }^{1}$ Çukurova Üniversitesi, Ziraat Fakültesi, Gıda Mühendisliği Bölümü, Adana, Türkiye. \\ * firuza.koboyeva@gmail.com
}

\section{Özet}

Kazakistan Orta Asya bağımsız Türk devletlerinden biri olup, 2724902 km² alan ile dünyanın en büyük dokuzuncu ülkesidir. Ülke ekonomisi metalürji, madencilik, tarım ve hayvancılığa dayalıdır. Süt endüstrisi, Kazakistan gıda endüstrisinin önde gelen sektörlerinden biridir. Ülkede üretilen süt ürünleri genellikle inek sütünden yapılmaktadır. İnek sütünün yanı sıra keçi, koyun, kısrak ve deve sütlerinden de geleneksel olarak yapılan süt ürünleri mevcuttur. Ülkede üretilen süt ve süt ürünleri; pastörize ve UHT sütler $(\% 0.5, \% 1.5$, \%2.5, \%3.2, \%6 yağ oranlarına sahip), yoğurt, meyveli yoğurtlar, dondurma, ayran, kefir, lor, krem peyniri, çökelek, eritme peyniri, Beyaz peynir (Brınza), kaymak ve tereyağı olarak sıralanabilmektedir. Ayrıca Kımız, Saumal, Şubat, Kurut, Süzbe, Irımşık, Aklak ve Katık gibi çeşitli geleneksel süt ürünleri küçük çaplı işletme ve ev işletmelerinde de üretilip pazarlarda satışa sunulmaktadır. Bu araştırmada Kazakistan'ın süt üretimi ve süt ürünleri incelenmiş ve Kımız, Şubat ve Kurut gibi geleneksel süt ürünlerinin özellikleri ve üretimleri ile ilgili bilgiler verilmiştir.

Anahtar Kelimeler: Kazakistan, süt üretimi, süt endüstrisi, geleneksel süt ürünleri

\section{Milk Production and Dairy Industry of Kazakhstan}

\begin{abstract}
Kazakhstan is an independent Central Asian country which is the 9th largest in the world, with an area of $2724902 \mathrm{~km}^{2}$. The economy of this country is based on metallurgy, mining, agriculture, and livestock farming. The dairy industry is one of the leading sectors of the food industry in the Kazakhstan. Dairy products produced in the country are usually made from cow milk. Besides the cow's milk, there are also dairy products made traditionally from goat, sheep, mare, and camel milk. Milk and dairy products produced in the country are pasteurized and UHT milk (with $0.5 \%, 1.5 \%, 2.5 \%, 3.2 \%, 6 \%$ of fat ratio), yogurt, fruit yogurt, ice cream, buttermilk, kefir, curd cheese, cream cheese, processed (melting) cheese, white cheese (Bryndza), cream, and butter. Various traditional dairy products such as Kymyz (Kimiz), Saumal, Shubat, Kurt, Suzbe, Irimshik, Aklak, and Katyk are also produced in small dairy and cheese factories or home factories and sold in local markets. In this research, the milk production and dairy products of the Republic of Kazakhstan is studied and detailed information about the characteristics and production of traditional dairy products such as Kymyz, Shubat and Kurt of the country is presented.
\end{abstract}

Keywords: Kazakhstan, milk production, dairy industry, traditional dairy products 


\section{GíRiş}

Kazakistan Avrasya kıtasının merkezinde yer alan $2724902 \mathrm{~km}^{2}$ alanla dünyanın en büyük 9. ülke olup 1991 yılından itibaren bağımsız bir devlettir [1]. Ülkenin kuzeyinde Rusya, güneyinde Türkmenistan, Özbekistan, Kırgızistan, doğusunda ise Çin Halkı Cumhuriyeti bulunmaktadır. Ulusal Ekonomi Bakanlığ İstatistik Komitesi tarafindan yayınlanan 1 Ocak 2020 yılı verilerine göre Kazakistan'ın nüfusu 18632200 olarak hesaplanmıştır [2]. Nüfus yoğunluğu yüzölçümüne göre düşük olmasına rağmen, ülke ekonomisi orta derecede gelişmiş ülkeler düzeyindedir [3]. Ülke topraklarının 1/5'i dağlarla kaplıyken diğer kısmı düzlükler, tepelik ovalar ve platolardan oluşmaktadır. Vadi ve ovalarında çok sert bir karasal iklimi hakimdir ve sicaklık bölgelere göre $-40^{\circ} \mathrm{C}$ 'den $+40{ }^{\circ} \mathrm{C}$ 'ye kadar farkl1lık göstermektedir $[1,4]$.

Kazakistan Cumhuriyetinin ekonomisi metalürji, madencilik, tarım ve hayvancılığa dayalıdır. Toprakların büyük bölümü çöl ve dağlarla kaplı olmasına rağmen Orta Asya Türk Cumhuriyetleri arasında en büyük tarımsal potansiyele sahip bir ülkedir. Yüzölçümün \%75'i tarıma elverişli araziden oluşmaktadır [5]. Ülke, \%75'nin 30'u ekilebilir arazi ve meralardan oluşan geniş bir tarım alanı ile dünya sıralamasında altıncı siradadir [3, 6].

Kazakistan'da tarım, hayvansal ve bitkisel üretim olmak üzere iki temel alana dayanmaktadır. Çiftçiliğin büyük kısmını sığır, at ve deve gibi büyükbaş hayvan ve koyun yetiştiriciliğinin yanı sıra süt ürünleri, deri, et ve yün üretimi oluşturmaktadır. Ülkenin Orta ve Güneybatı bölgelerindeki çöl ve yarı çöl bölgeleri genellikle çiftlik hayvanları için mevsimlik meraları olarak kullanılırken, Doğu ve Güneydoğusundaki dağ çayırları yaz otlakları olarak kullanılmaktadır [7].

Kazakistan' da tarım aşağıda verilen dört ayrı bölge şeklinde de incelenebilir;

- Bat1 Kazakistan Bölgesi: deve, koyun ve atların yetiştirildiği bölgedir; ekilebilir arazinin \%70’inde buğday yetiştirilirken geri kalanında çavdar, darı ve arpa ekilmektedir;

- Güney Kazakistan Bölgesi: pamuk, şeker pancarı, tütün, kendir, yağlı tohumların ve pirincin hasat edildiği suni sulamalı bölgedir;

- Doğu Kazakistan Bölgesi: buğday, ayçiçeği, yulaf, bezelye ve bazı sebzelerin yetiştirilmesinin yanı sıra et-süt hayvancılığının yapıldığı yerleşik tarımsal bölgedir;

- Kuzey Kazakistan Bölgesi: başta koyunların beslendiği bölge olmak üzere et-süt hayvancilığı ve kuş yetiştiriciliğinin ve pamuğun hasat edildiği bölgedir $[1,8]$.

Ülkenin ekonomisinde en önemli rollerden birini gıda endüstrisi oynamakta ve bu sektör çeşitli bitkisel ve hayvansal gıda ürünlerinin üretimini gerçekleştiren çok sayıda alt sektörden oluşmaktadır. Kazakistan İstatistik Komitesi'ne göre 2017 yılında gıda sektörünün ülkenin toplam sanayi üretimi içindeki pay1 \% 7.0, imalat sanayi içerisindeki payı ise \%19.8 olarak hesaplanmıştır [9]. Ülkede gıda endüstrisi; et ürünleri, balık, firıncılık, süt ürünleri, şeker, pasta-kurabiye, makarna, tereyağı ve sıvı yağ, meyve konserveleri, şarap, bira, çay ve diğer endüstrileri içermektedir [10]. Hayvansal gıdalar arasında en çok tüketilen \%35 ile süt ürünleri olup, bunu \%10 ile et ve yaklaşı \%5 ile yumurta izlemektedir [3, 4].

$\mathrm{Bu}$ çalışmanın amacı Kazakistan Cumhuriyetinin mevcut süt sektörünün durumunu incelemek ve işletme şartlarında üretilen süt ve süt ürünlerinin yanı sıra geleneksel olarak ev şartlarında üretilen süt ürünlerinin özellikleri ile birlikte üretim yöntemlerini araştırmaktır.

\section{KAZAKISTAN SÜT ÜRETIMI}

Süt hayvancılığ 1 ve süt endüstrisi Kazakistan Cumhuriyetinin tarımsal sanayi kompleksinin en önemli alt sistemlerinden biridir [11]. Yapılan araştırmalara göre 2019 yılında yalnızca süt ürünleri üretim miktarı açısından tüm gıda ürünlerinin \%18.8'ini kapsamıştır. Ancak, ülke tarımsal üretimin gelişimi için yüksek doğal ve iklimsel potansiyele sahip olmasına rağmen, süt ürünlerinin üretimi ve tüketimi istenilen düzeye ulaşamadığı da bildirilmektedir [12]. 
Süt sektörünün gelişmesini önleyen en büyük iki doğal faktörü; geniş toprak kaynaklarının önemli kısmının tundra, bozkır veya çöl olduğundan ekim için kullanılamaması ve çok sayıda terkedilmiş tarım arazilerinin var olması olarak rapor edilmiştir [13]. Günümüzde ülkenin süt endüstrisindeki sorunları ortadan kaldırmak adına araştırmalar yürütülmekte ve birçok yerel firma/işletme yeni projelerin hayata geçmesi için çalışmaktadır.

Ülkede yaklaşık olarak 8 milyon büyükbaş hayvan sayısının \%67.2'si süt sektöründe değerlendirilirken, kalan \%32.8'i et sektöründe değerlendirilmektedir [14]. Kazakistan Cumhuriyeti Ulusal Ekonomi Bakanlığı İstatistik Komitesi'ne (KCUEBİK) göre Şekil 1 ve 2'den de görüldüğü üzere 2014-2020 yıllar arasında büyükbaş ve küçükbaş hayvan varlığı her yıl düzenli bir artış göstermiştir.

Ocak ayı bazında 2015-2020 yılları arasında koyun ve keçi varlığ $1 \% 6.9$ oranında artarak 19155.7 bin başa, büyükbaş hayvan varlığ $1 \% 23.3$ oranında artarak 7436.4 bin başın üzerine, at varlığ $\% 47.2$ oranında artarak 2852.3 bin başa ve deve varlığ1 \%30.4 oranında aratarak 216.4 bin başa yükselmiştir (Şekil 1). 2019 yılı ile kıyaslandığında ise bu artış oranları sırasıyla \%2.4, \%4.0, \%7.8 ve \% 4.2 olarak hesaplanmıştır [14-17].

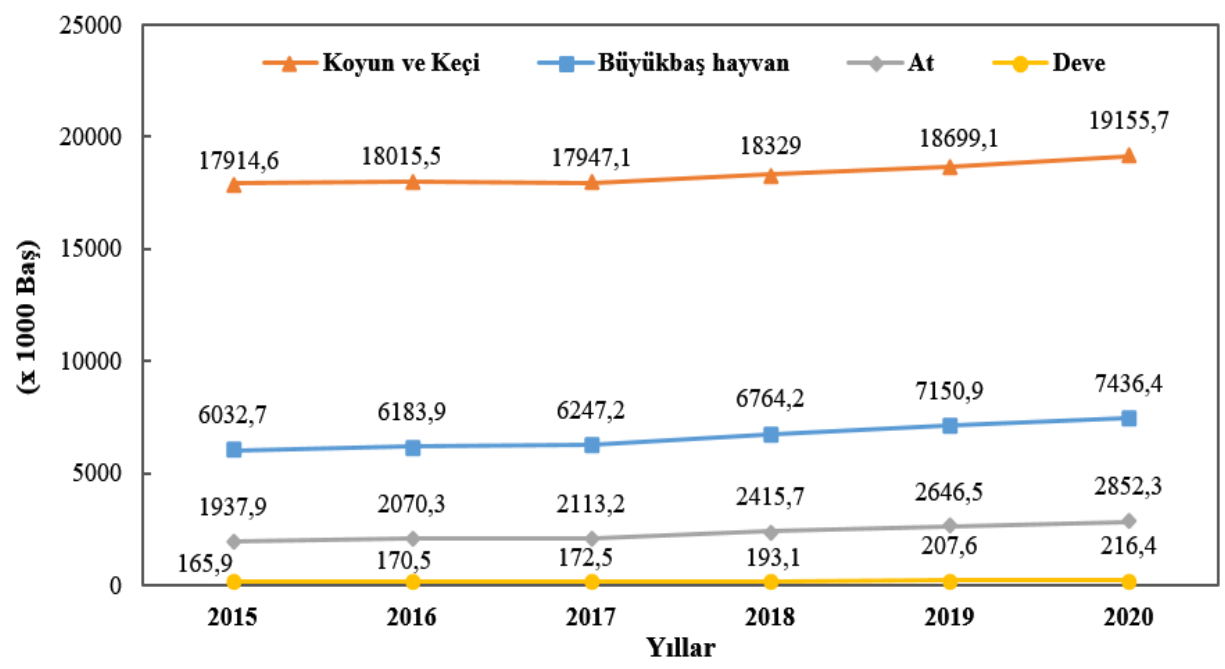

Şekil 1. Büyükbaş ve küçükbaş hayvan varlığı (Ocak ayı bazında) (x 1000 baş)

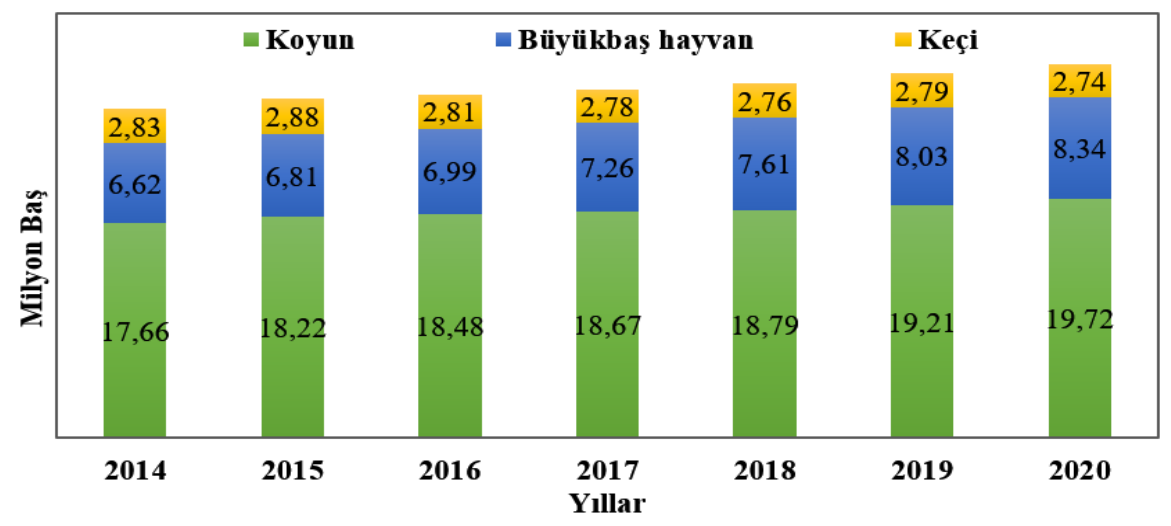

Şekil 2. Büyükbaş ve küçükbaş (koyun ve keçi) hayvan varlığı (Mart ayı bazında) (milyon baş)

Mart ayı bazında ise büyükbaş hayvanlar arasında 2020 yılında 8.34 milyon baştan 3.8 milyon baş sayısıyla en çok inek yetiştirilirken, küçükbaş hayvanlar arasında 19.72 milyon baş sayısı ile koyun varlığı olup, en düşük seviyede 2.74 milyon sayısı ile keçi yetiştiriciliği yapılmaktadır (Şekil 2) [14]. 
Ülkede bakım ve beslenme koşullarının iyileştirilmesi, üreticilerin süt hayvancılı̆̆ı konusunda bilinçlenmesi, hayvan sayısındaki artış ile birlikte hayvan başına süt verimi seviyesi de yükselmiştir. Tablo 1'den de görüldüğü üzere sağılan toplam inek sayısı 2018 yılında bir önceki yıla göre \%3.2 artışla ve 2005 yılına göre \%9.3 artışla 2411 bin baş olarak hesaplanmıştır. Sağılan inek başına süt verimi ise bir önceki yıla göre \%0.1 ve 2005 yılına göre \%10.0 oranında artarak hayvan başına süt verimi $2340 \mathrm{~kg} / \mathrm{baş} \mathrm{olarak}$ hesaplanmıştır. Toplam inek sütü üretim miktarları, sanayiye aktarılan inek sütü miktarları ve içme sütü (krema dahil) üretim miktarları Tablo 2'de verilmiş ve bu verilerin oluşturduğu grafik Şekil 3'te gösterilmiştir.

Tablo 1. Kazakistan'da sağılan inek sayısı ve inek başına süt verimi

\begin{tabular}{llllllc}
\hline & \multicolumn{5}{c}{ Yıllara göre dağılım } \\
\cline { 2 - 7 } & $\mathbf{2 0 0 5}$ & $\mathbf{2 0 1 0}$ & $\mathbf{2 0 1 5}$ & $\mathbf{2 0 1 7}$ & $\mathbf{2 0 1 8}$ & $\mathbf{2 0 1 7 - 2 0 1 8}$ Değişim \\
\hline Sağılan inek sayısı (x 1000 baş) & 2206 & 2371 & 2216 & 2337 & 2411 & $+\% 3.2$ \\
İnek başına süt verimi (kg/baş) & 2127 & 2255 & 2321 & 2337 & 2340 & $+\% 0.1$ \\
\hline
\end{tabular}

Kaynak: [18]

Tablo 2. Kazakistan' da toplam süt üretim miktarları (bin ton)

\begin{tabular}{lccccccc}
\hline \multirow{2}{*}{ Süt ürünleri } & \multicolumn{7}{c}{ Yıllara göre dağlım } \\
\cline { 2 - 8 } & $\mathbf{2 0 0 5}$ & $\mathbf{2 0 1 0}$ & $\mathbf{2 0 1 5}$ & $\mathbf{2 0 1 6}$ & $\mathbf{2 0 1 7}$ & $\mathbf{2 0 1 8}$ & $\mathbf{2 0 1 7 - 2 0 1 8}$ Değişim \\
\hline İnek sütü üretimi & 4693 & 5348 & 5182 & 5300 & 5460 & 5642 & $+\% 3.3$ \\
Sanayiye aktarılan inek sütü miktarı & 750 & 1300 & 1550 & - & 1950 & 2150 & $+\% 10.3$ \\
İçme sütü ve krema üretimi & 180 & 295 & 467 & 499 & 482 & 536 & $+\% 11.1$ \\
\hline
\end{tabular}

Kaynak: [18, 19]

İnek sütü üretimi dünyanın farklı ülke ve bölgelerinde farklı oranlarda artıp azalırken, 2018 yılında dünya toplam inek sütü üretimi bir önceki yıla göre \% 2.1 oranında artmıştır. Asya'da toplam inek sütündeki artış oranı $\% 4.8$ oranında artarken Kazakistan'da toplam inek sütü üretimindeki artış oranı \%3.3 olarak hesaplanmıştır (Tablo 2) [18]. Ülke 2018 yılında toplam süt üretim miktarı açısından 5642.2 bin ton ile dünya sıralamasında 35. sırada yer almıştır [20]. KCUEBİK'e göre 2019 yılında toplam süt üretim miktarı bir önceki yıla göre \%3.1 oranında artarak 5820.1 bin ton olarak hesaplanırken 2020 yılın Ocak-Ekim ayları arasındaki toplam süt üretim miktarı 5270.5 bin ton olarak hesaplanmıştır.

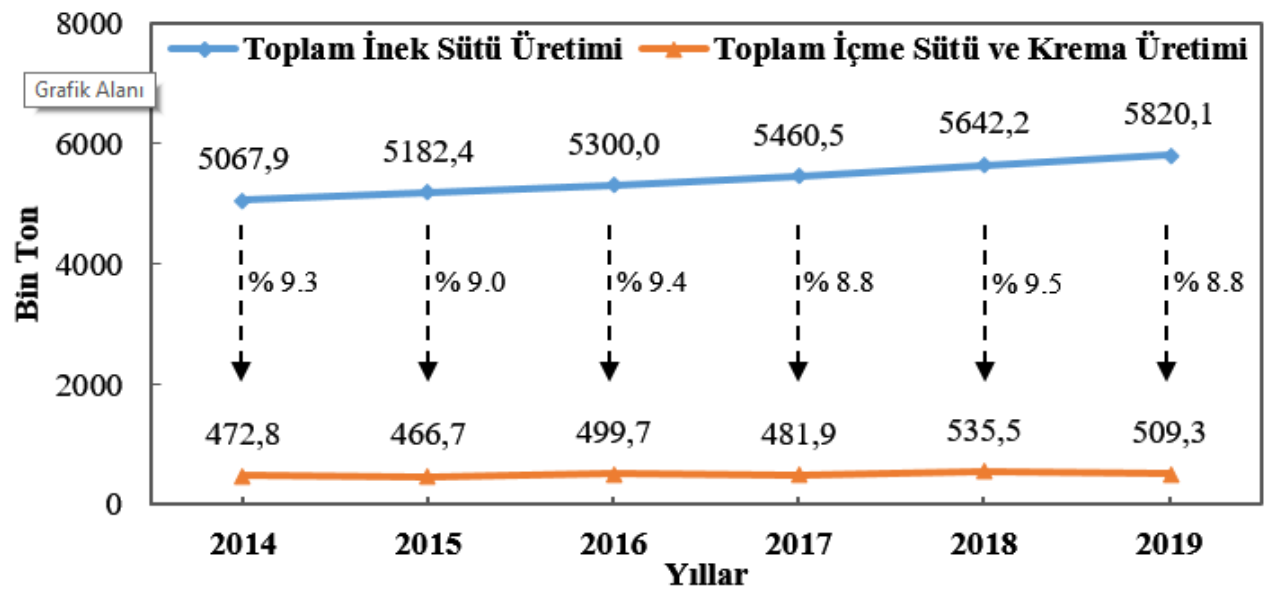

Şekil 3. Kazakistan'da toplam süt üretim miktarları ve yüzdelik payı ile birlikte içme sütü (krema dahil) üretim miktarları (bin ton) 
Süt endüstrisinde çiğ süt fiyatının yüksek olması, sığır verimliliğinin düşük olması ve yüksek kaliteli yeme ulaşamama gibi nedenlerden dolayı süt üretiminin karlılığı nispeten düşük seviyededir.

Tablo 2'den de anlaşıldığı üzere yaklaşık 5.5 milyon ton çiğ süt elde edildiğinde sanayide yalnızca 2 milyon tonu işlenebilmektedir. Bununla birlikte bu miktarının yalnızca yaklaşık \%50'si Gümrük Birliğinin belirlediği standartlara uygunluk göstermekte ve kalan miktar hiç bir şekilde sanayide kullanılamamaktadır $[21,22]$. Sütün kalite özelliklerinin iyileşmesi ve süt ürünleri yelpazesinin genişlemesi için 01 Ocak 2020'den itibaren süt üreticilerini Avrasya standartlarına göre çalışmaya zorlayacak özel Avrasya Ekonomik Birliği (EAEU: Eurasian Ecomonic Union) standartlarının yürürlüğe girmesi planlanmıştır. Ancak ülkede faaliyet gösteren birçok süt ve süt ürünleri işletmelerinin hazırlık sürecinin tamamlanamaması nedeniyle bu standartların uygulanması için son tarih 01 Ocak 2025 tarihine kadar uzatılmıştır [19, 23, 24].

Süt ürünleri yaş, ikamet yeri ve maddi gelirine bakılmaksızın dünyanın gelişmiş ülkelerine benzer şekilde Kazakistan nüfusunun da tüm kategorileri arasında popülerdir. Ülkede üretilen süt ve süt ürünleri; pastörize ve sterilize (UHT) sütler, yoğurt, meyveli yoğurt, biyo-yoğurt, probiyotik yoğurt, kefir, ayran, dondurma, lor, tereyağı, krem peyniri, çökelek, eritme peyniri ve kaymak olarak sıralanabilir. Ülkenin birçok işletmesinde Beyaz peynir (Brınza), Suluguni, Kostromskiy gibi sert tipi peynirler de üretilmektedir. Toplam süt ve süt ürünlerinin üretim miktarları Tablo 3'te verilmiş ve bu Tablo'dan da anlaşıldığı üzere tüm ürünlerin üretim miktarları her yıl artış göstermektedir.

Tablo 3. Toplam süt ve süt ürünleri üretim miktarları (ton)

\begin{tabular}{|c|c|c|c|c|c|c|}
\hline \multirow[b]{2}{*}{ Süt ve süt ürünleri } & \multicolumn{6}{|c|}{ Yıllara göre dağılım } \\
\hline & 2014 & 2015 & 2016 & 2017 & 2018 & $\begin{array}{l}\text { 2017-2018 } \\
\text { Değisisim }\end{array}$ \\
\hline İçme Sütü ve Krema & 472835 & 466726 & 499709 & 481888 & 535501 & +11.1 \\
\hline Peynir ve Lor & 22192 & 30681 & 24692 & 25192 & 27546 & +9.3 \\
\hline Taze Peynir ve Lor & - & - & 17936 & 17653 & 18518 & +4.9 \\
\hline Yağsız Lor & 5090 & 5494 & 6939 & 7069 & 6435 & -9.0 \\
\hline Yağlı Lor & 9274 & 9108 & 9045 & 7831 & 8826 & +12.7 \\
\hline $\begin{array}{l}\text { Peynir (eritme peyniri hariç } \\
\text { rendelenmiş, toz, mavi ve } \\
\text { işlenmemiş peynirler) }\end{array}$ & - & - & 4491 & 5198 & 7456 & +43.4 \\
\hline Sert Peynirler & 2926 & 2976 & 3416 & 4256 & 5048 & +18.6 \\
\hline Yumuşak Peynirler & - & - & 248 & 310 & 496 & +60.0 \\
\hline Salamura Peynirleri & - & - & 665 & 843 & 1013 & +20.2 \\
\hline $\begin{array}{l}\text { Eritme Peynirleri (rendelenmemiş } \\
\text { ve toz haline getirilmemiş) }\end{array}$ & - & - & 2265 & 1621 & 1572 & -3.0 \\
\hline Tereyağı & 15702 & 17072 & 16591 & 16840 & 17000 & +1.0 \\
\hline Diğer Süt Ürünleri & - & - & 213934 & 215232 & 219142 & +1.8 \\
\hline $\begin{array}{l}\text { Koyulaştırılmış Süt ve Krema } \\
\text { (şeker veya diğer şeker ikame } \\
\text { maddeleri ilaveli veya ilavesiz) }\end{array}$ & 9147 & 6780 & 9199 & 9224 & 8259 & -10.5 \\
\hline Yoğurt, Fermente Süt ve Krema & 179785 & 187123 & 191581 & 192895 & 198575 & +2.9 \\
\hline Kımız & - & - & 655 & 958 & 890 & -7.1 \\
\hline Subat & - & - & 1983 & 1619 & 1807 & +11.6 \\
\hline
\end{tabular}

Toplam ithalat ve ihracat değerleri incelendiğinde Kazakistan'da süt ve süt ürünlerinin ithalat oranı 2019 yılında 2018 yılına göre \%1.15 oranında artarak 137 bin ton olarak hesaplanırken ihracat değeri \%38.3 oranında artarak 58.5 bin tona yükselmiştir [20]. Süt ve süt ürünleri ithalatı en çok Beyaz Rusya, Rusya, 
Avrupa Birliği, Ukrayna ve Kırgızistan'dan yapılırken, ihracat en çok Rusya, Kırgızistan ve Özbekistan ülkelerine yapılmaktadır.

Kazakistan'da üretilip satışa sunulan süt ve süt ürünlerinin özellikleri ve üretim yöntemleri ile ilgili bilgiler aşağıda verilmiştir.

\section{KAZAKISTAN SÜT ÜRÜNLERI}

\section{1. İçme sütü}

Kazakistan'da dünyanın birçok ülkesinde olduğu gibi çocuk beslenmesinde önemli yere sahip ve yetişkinlerin genellikle (\%95) çeşitli yemeklerde kullandığı süt inek sütüdür. Piyasada $\% 0.5, \% 1.5, \% 2.5$, $\% 3.2$ ve \%6 yağ oranına sahip pastörize veya UHT inek sütlerinin pazarlanması yanı sıra pastörize koyun veya keçi sütleri de bulunmaktadır. Bununla birlikte Orta Asya ülkelerine özgü at (kısrak) sütü ve deve sütü kullanımı günümüzde halen devam etmekte, hatta gün geçtikçe tüketiminde artışlar da belirlenmektedir. Bu sütler genellikle geleneksel fermente süt ürünlerin üretiminde kullanılmaktadır.

Şekil 3'te de gösterildiği gibi 2019 yılında toplam 5.8 milyon ton sütten yalnızca \%8.8'i (509.3 bin ton) içme sütü ve kremaya işlenmiştir. Bu oran 2017 yılındaki oranla aynı olup 2014-2016 ve 2018 yılındaki oranlardan daha düşük çıkmıştır.

Toplam inek sütü ve krema üretim miktarlarına bakıldığında (Tablo 3) ülkede 2018 yılında bir önceki yıla göre \%11.1 oranında artış belirlenmiş ve üretilen süt miktarı (krema dahil) 535 bin 501 tona ulaşmıştır [26]. 2019 yılı Aralık ayında başlayan ve günümüzde halen devam eden COVID-19 salgının ortaya çıkmasıyla birçok ülkede çeşitli gıdaların üretilmesi ve işlenmesinde yavaşlamalar tespit edilmiş dolayısıyla üretim miktarlarında da azalmalar belirlenmiştir. Ancak Kazakistan'da 2020 yılın birinci dört aylık sürecinin süt ve süt ürünlerin üretim miktarlarına bakıldığında bir önceki yılın aynı periyoduna göre \%1.3 oranında artış belirlenmiş ve toplam 184.5 bin ton süt ve krema üretilmiştir [27].

Ulusal Ekonomi Bakanlığı İstatistik Komitesi'ne göre Kazakistan'da süt ve kremanın (konsantre edilmemiş) ithalatı 2019 yılında bir önceki yıla göre \%1.3 oranında artarak 21.5 bin ton olarak hesaplanmıştır. 2015 yılı ile kıyaslandığında ise bu değer \%53.5 oranında düşüş göstermiştir. Konsantre edilmiş süt ve krema ithalatı ise 2019 yılında 2018 yılına göre \%14.7 oranında düşerek 37.6 bin ton olarak hesaplanmıştır.

İhracat değerleri incelendiğinde 2019 yılında bir önceki yıla göre süt ve krema (konsantre edilmemiş) ve süt ve krema (konsantre edilmiş) sırasıyla \%43.8 ve \%24 oranlarında artarak 39.4 bin ton ve 910 ton olarak hesaplanmıştır [20]. Yine COVID-19 pandeminin ortaya çıkmasıyla birçok ülkenin ithalatı ve ihracatı durdurulduğu gibi Kazakistan'da da aynı durum söz konusu. Ülke bu süreçte gıda açısından kendi ihtiyaçlarını karşılayabilse de ekonomik bakımından ülkenin bütçesi düşük ihracat değerinden dolayı ilerleyen süreçlerde büyük zarar görebilir.

Kazakistan nüfusunun ortalama süt tüketim miktarları Şekil 4'te verilmiştir. 2019 yılında süt ve süt ürünlerinin fiyatlarının artması ile tüketim miktarında azalmalar belirlenmiştir. Çiğ süt üretim miktarı ile aynı yıla ilişkin nüfus verileri ele alındığında ve süt ve süt ürünleri ithalat ve ihracat rakamları da dahil edildiği bir hesaplama ile 2019 yılında bir önceki yıla göre kişi başı süt tüketim miktarı \%3.1 oranında düşerek ortalama $253 \mathrm{~kg} /$ kişi olarak hesaplanmıştır. Beş yıllık değişime (2015-2019) bakıldığında ise ortalama süt tüketim miktarında \%11.2 oranında düşüş belirlenmiştir $[19,20]$. Ülkede kayıtlı içme sütü üretim miktarları ve dış ticaret verileri ile entegre süt işletmeleri tarafından toplanan süt miktarı haricinde üretilen süt miktarı ele alındığında; 2019 yılının ikinci dört aylık sürecindeki ortalama kişi başı süt tüketim miktarı bir önceki yılın aynı periyoduna göre \%3.8 oranında düşerek $63.3 \mathrm{~kg}$ (litre) olarak belirlenmiştir [28]. 


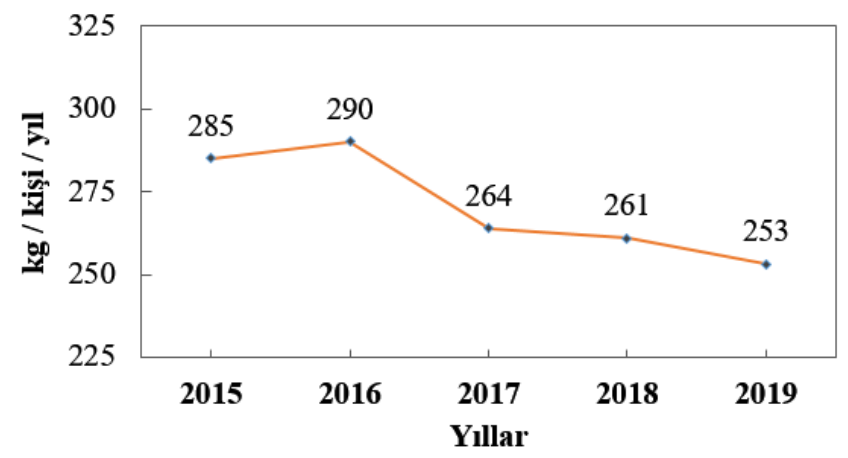

Şekil 4. Kazakistan'da ortalama süt tüketim miktarları (2015-2019)

\subsection{Yoğurt}

Sütte olduğu gibi fermente süt ürünleri üretim miktarları da her yıl artış göstermektedir. Tablo 3 'ten de görüldüğü üzere 2018 yılında 2017 yılına göre toplam yoğurt, fermente süt ve krema üretim miktarı \%2.9 oranında artarak 198 bin 575 ton olarak hesaplanmıştır [19].

Kazakistan'da ilk yoğurt 1995 yılında "FoodMaster" süt işletmesi tarafından piyasaya sürülmüştür. Günümüzde de bu şirket ülkede süt ve süt ürünleri üretimi açısından ilk sırada yer almaktadır [29].

Sade yoğurdun yanı sıra çeşitli meyveli yoğurtların, probiyotik yoğurtların ve biyo-yoğurtların üretimi de gerçekleştirilmektedir. Genel olarak yoğurtlar,

- Yağ oranına göre; \%3.5 yağl1 sütten üretilen klasik, yarım yağl1, az yağl1 ve yağsız yoğurtlar şeklinde siniflandirılmaktadır.

- Kullanılan katkı maddelerine göre; klasik (doğal, katkısız), meyveli (çilek, yaban mersini, şeftali, ahududu, kiraz, kayısı, limon, mango vb.) ve aromatize edilmiş (çikolata, vanilya, karamel, zencefil vb.) yoğurtlar olarak sınıflandırılabilir.

Yoğurt üretiminde kullanılan bakteriler genellikle Avrupa'dan, süt tozu Beyaz Rusya, Rusya ve Ukrayna'dan ve tatlandırıcılar en çok Rusya'dan ithal edilmektedir. Kazakistan'da üretilen yoğurtlar ise ülke içerisinde kendi tüketimi yanı sıra en çok Kırgızistan ve Özbekistan'a ihracat edilmektedir [30].

Fermente süt ürünlerinin ithalatı 2019 yılında bir önceki yıla göre \%12.9 oranında artarak 36 bin ton olarak hesaplanırken ihracat $\% 15$ oranında artarak 11 bin tona ulaşmışırı [20].

\subsection{Kefir ve Ayran}

Fermente süt ürünleri arasında önemli yeri teşkil eden kefir piyasada $\% 1, \% 2.5$ ve $\% 3.2$ yağ oranlarında bulunmaktadır. Birçok süt ürünün ambalajlanmasında kullanıldığı gibi kefirde de Tetra Brik (500 ve 1000 g) veya plastik şişeler (900 g) kullanılmaktadır.

Son yıllarda Kazakistan'da süt ürünleri arasında \%1.5 yağ oranına sahip Türk ayranı da yer almaya başlamıştır. Üretimde süt, tuz ve sudan başka hiçbir katkı maddenin kullanılmaması ve hafif tuzlu olması tüketicilerin damak tadına uymuş ve ürün hızlı bir şekilde yayılmaya başlamıştır [31].

\subsection{Tereyağı}

Tablo 3'ten de anlaşıldığı üzere Kazakistan'da 2018 yılında bir önceki yıla göre toplam tereyağ üretim miktarında çok büyük değişimler belirlenmemiştir. Ancak 2015 yılı ile kıyaslandığında 2018 yılında tereyağı üretim miktarında \%8.3 oranında artış tespit edilmiştir [19]. 2020 yılın ilk dört ayın üretim 
miktarlarına bakıldığında bir önceki yılın aynı periyoduna göre $\% 15$ oranında artış belirlenmiş ve toplam 6 bin ton tereyağı üretilmiştir [32].

Ülkeye 2019 yılında yaklaşık olarak 5 bin ton tereyağ ithal edilmiş ve 2018 y1lına göre düşüş oranı \%22.3 olarak hesaplanmıştır. İhracat durumu incelendiğinde ise 2019 yılında bir önceki yıla göre $\% 57$ oranlı artışla 2.8 bin tona ulaşmıştır [20].

\subsection{Peynir}

Kazakistan'da peynir üretimi diğer gelişmiş ülkelere göre daha düşük düzeyde olmasına rağmen son yıllarda üretimindeki artış miktarı ve pazardaki eğilimler ümit vericidir. Örneğin, 2018 yılında peynir ve lor üretim miktarı bir önceki yıla göre \%9.3 ve 2014 yılına göre \%24.1 oranında artarak 27 bin 546 tona ulaşmıştır (Tablo 3). Peynir ve lor ithalatı 2019 yılında 2018 yılına göre \%16.3 oranında artarak 25.6 bin ton olarak hesaplanırken ihracat \%44.6 oranında artarak 3.4 bin tona yükselmiştir [20].

Tüketim açısından da 2017 yılında kişi başına düşen ortalama peynir tüketim miktarı $2.5 \mathrm{~kg}$ ile diğer ülkelere göre düşük düzeydedir. Ülkenin en gelişmiş ve en kalabalık nüfusuna sahip Almatı ve Nur-Sultan (eski adı Astana) şehirlerinde ikamet edenlerin yıllık peynir tüketim miktarı en yüksek olup sırasıyla 4.5 ve $3.8 \mathrm{~kg}$ olarak rapor edilmiştir [25].

Kazakistan Cumhuriyetinde faaliyet gösteren büyük çaplı süt işletmelerinde Beyaz peynir (Brınza), Feta, Rondele, Mozzarella, Mascarpone gibi taze peynirler; Emmental, Edam, Madrigal, Maasdam, ParmigianoReggiano, Grana Padano gibi sert tipi peynirler; Camembert, La Brique, Brie gibi yumuşak peynirler; La Blue gibi mavi küflü peynir; Shevret (Chevres Doux), Rondele gibi keçi peynirleri üretilmektedir [31].

Bununla birlikte son yıllarda ülkenin bazı bölgelerinde kaliteli peynir arayışında olan birkaç tüketici yurtdışında gerçekleştirilen çeşitli peynir eğitim kurslarına katılıp ev işletmelerinde yabancı tip peynirlerinin üretimlerine başlamıştır. Bu peynirler arasında Buratta, Mozzarella, Ricotta, Gouda, Belper Knolle, Strakkino, Philadelphia (Krem peynir), Village cheese (Köy peyniri), Kachotta, Adige, otlu Adige, Hellim, Labneh vd. peynirler yer almaktadır.

Ayrıca Sovyetler Birliği'nin dağılışından sonra Kazakistan'da kalıp yaşamlarını sürdüren Ahıska (Kafkas) Türkleri, Tatarlar ve diğer milletler kendi ihtiyaçlarını karşılamak için ev şartlarında yoğurt, Beyaz peynir (Brınza), Çeçil, Çökelek, Şor, kaymak, tereyağı vb. süt ürünleri yaparak yerel pazarlarda satışa sunmaktadir.

\subsection{Dondurma}

Kazakistan'da dondurma üretimi süt ve süt ürünleri sektörünün en gelişmiş alt birimlerinden biridir denilebilir. Ülkede yaklaşık 100 çeşit dondurma üretimini gerçekleştiren 20'den fazla dondurma işletmesi faaliyet göstermektedir. En çok tüketilen dondurma çeşitleri sade dondurma ("Plombir"), çikolatalı, koyulaştırılmış süt ilaveli, cevizli, karamelli dondurmalardır. Bunun yanı sıra birçok meyveli dondurma, incirli-yoğurtlu, fındıklı-çikolatalı, kayısılı-çikolatalı gibi dondurmaların üretimi de gerçekleştirilmektedir. Dondurma iç pazarı yanı sıra Rusya, Tacikistan, Kırgızistan, Özbekistan ve Moğolistan gibi Orta Asya ülkelerine de ihracat edilmektedir [33, 34].

Kazakistan'da standart bir tat ve aromaya sahip olmayan ancak sağlığa çok yararlı olan Kımız ve Şubat gibi kısrak ve deve sütünden yapılan geleneksel içecekleri kullanılarak dondurma üretimi de yapılmaktadır. Dondurmanın yaklaşık \%45'ini geleneksel içecekler oluştururken, kalan kısmı \%35 yağ oranlı krema, yumurta sarısı ve şeker oluşturmaktadır. Üretime başka hiçbir katkı madde kullanılmamaktadır. İç ve dış pazarın taleplerini karşılamak için üretim tesislerinin büyümesi ve güçlenmesi için ülkede çeşitli çalışmalar da sürdürülmektedir $[35,36]$. 


\section{GELENEKSEL SÜT ÜRÜNLERİ}

Kazakistan'da üretim alanı ve geleneksel üretim yöntemi ile daha güçlü bir bağlantısı olan geleneksel gıda ürünlerine yönelik artan bir potansiyel talep bulunmaktadır [37]. Geleneksel süt ürünleri tüketici pazarının önemli bir kısmını oluşturmakta ve bu ürünler genellikle küçük çaplı işletme ve/veya ev işletmelerinde üretilip satılmaktadır. Orta Asya ülkelerine özgü geleneksel süt ürünleri Kımız, Saumal, Şubat, Kurt, Ayran, Uı, Sarısu, Irımşık (İrimşik), Sarımay, Süzbe, Aklak, Katık, Balkaymak vb. şeklinde sıralanabilir.

\subsection{Kısrak Sütü ve Kımız}

Kazakistan'da inek, koyun ve keçi yetiştiriciliği yanı sıra at ve deve yetiştiriciliği de yaygın şekilde yapılmaktadır. Şekil 1'den de görüldüğü gibi 2020 yılında Kazakistan' da yarısı kısrak olmak üzere yaklaşık olarak 2.9 milyon at yetiştirilmektedir.

Ülkede "Saumal" olarak da bilinen çiğ kısrak sütünün insan sağlı̆̆ı üzerinde önemli ölçüde olumlu etki gösterdiği, iyileştirici özelliklerine sahip olduğu bilinmektedir [38]. Ancak sütünün iyileştirici özellikleri sağımdan üç saat sonra azaldığı da bildirilmektedir. Ürünün kalitesini, biyoaktif bileşenlerini ve vitaminlerini korumak için süt sağımdan hemen sonra dondurulmakta veya dondurularak kurutulmaktadır. Toz haline getirilmiş kısrak sütünün özellikleri su ile karıştırıldığında taze Saumal'ın özelliklerini \%99 oranında taşıdığ da bildirilmektedir [37, 39]. Amerika Birleşik Devletleri, Birleşik Arap Emirlikleri, Çin, Rusya, Umman, Bahreyn, Suudi Arabistan gibi ülkelerinde de kısrak sütüne ilgi son yıllarda artmaktadır. Avrupada'da 30'dan fazla işletme kurutulmuş kısrak sütünün üretimini gerçekleştirirken dünyanın en büyük kısrak sütü işleme tesisi 2015 yılında Kazakistan'ın Karaganda bölgesinin Asykaryk eyaletininde faaliyete başlamıştır [40]. Avrupa ülkelerinde kurutulmuş "Saumal” gıda endüstrisinde kullanılmasının yanı sıra farmakolojide ve kozmetik sanayide de kullanılmaya başlamıştır. Kazakistan'da da üretimlerin büyümesi ile bu ürünün çeşitli endüstrilerde kullanımı planlanmaktadır [41].

Kımız (Kumıs, Kumiss, Koumiss, Kymyz, Kumys Qymyz veya Kumiz olarak da bilinir) özellikle Orta Asya'da ve en çok Kazakistan, Moğolistan ve Kırgızistan'da binlerce yıldan beri göçebe halklar tarafindan kısrak sütünden yapılan fermente süt ürünüdür [42-44]. Bazı üreticileri Kımız yapımında inek ve keçi sütünü de kullanmaktadır. Kımız yoğurt, kefir, ayran gibi besleyici özelliklere sahip, hatta bu içeceğin birçok hastalığa karşı iyileştirici (örneğin; vazodilatör olarak tüberkülozlu hastaların tedavisi için yararlıdır) etkisinin de olduğu bilinmektedir [38, 45-48].

Kımız, sıvı starter kültürü (geleneksel yöntemde eski kımı) kullanılarak laktik asit ve etil alkol fermentasyonu sonucu meydana gelmektedir. Geleneksel yöntemle Kımız'ın elde edilmesi için çiğ kısrak sütü eski Kımız'lardan alınan kültür ile bir "Saba" veya "Torsuk" olarak adlandırılan kaplar içerisinde mayalanıp 24 saat boyunca oda sıcaklığında fermentasyona bırakılmaktadır. Bu süreç içerisinde Kımız her iki saatte bir yarım saatten az olmamak koşuluyla ahşap sopa ile karıştırılmakta ve çalkalanmaktadır. Bazı üreticiler karıştırma işlemi sırasında taze kısrak sütünü de ilave etmektedir. Bir gün sonra hazır hale gelen Kımız plastik şişelere hava almayacak şekilde ağzı kapatılarak doldurulmakta ve hiç hareket ettirilmeyecek şekilde soğuk odalarda muhafaza edilmektedir [38]. Genellikle de soğuk veya soğutulmuş şekilde tüketilmektedir.

Kısrak sütü, inek veya keçi sütünden daha fazla şeker içerdiğinden, fermente edildiğinde kefire nazaran daha fazla alkol içermektedir [49]. Kazakistan'da Kımız'ın bileşimi, yapıldığı hammaddeye, işleniş şekline göre az çok farklılık göstermektedir. Laktik asit ve alkol miktarına göre; bir gün fermente edildiğinde zayıf (laktik asit $=\% 0.7$, etil alkol $=\% 1.0$ ), iki gün fermente edildiğinde "Kunan Kumıs" olarak bilinen orta sert Kımız (laktik asit $=\% 1.1$, etil alkol $=\% 1.8$ ) ve üç gün fermente edildiğinde "Donen Kumıs" olarak bilinen sert Kımız (laktik asit $=\% 1.8$, etil alkol $=\% 2.5$ ) olmak üzere üç tip şeklinde sınıflandırılmaktadır. Sade Kımız'ın içerisine taze kısrak sütü katıldığında "Juas Kumıs" olarak bilinen içecek elde edilirken, bal, kayısı veya üzüm eklendiğinde "Balkumıs" olarak adlandırılan bir içecek ortaya çıkmaktadır. Yedi gün ve 
daha fazla süre fermente edilen Kımız içeceği halk arasında "Toneme Kumıs" olarak isimlendirilmektedir $[50]$.

\section{2. Şubat}

Dünaya'da kısrak sütünden çok daha ünlü ve popüler olan deve sütü [40] Kazakistan'da yüzyıllardır Şubat olarak bilinen geleneksel fermente içeceğin yapılmasında kullanılmaktadır. KCUEBİK verilerine göre 2020 yılında Kazakistan'da deve sayısı 216.4 bin baş olarak hesaplanmıştır. Develerin yetiştirildiği ana bölgeler; Atırau, Mangistau, Kızılorda ve Güney Kazakistan Bölgeleridir [51]. Şubat içeceği, Moğolistan, Özbekistan, Türkmenistan ve Rusya'nın bazı bölgelerinde de yaygın şekilde yapılıp tüketilmektedir [52].

Deve sütü, kısrak sütü ve anne sütü gibi albüminli sütler grubuna girmekte ve yüksek oranda içerdiği laktoferrin ve immunoglobülin sayesinde antioksidan aktiviteye sahiptir. Kazakistan'da Şubat içeceği tüberküloz, gastroenterit ve birçok enfeksiyon tedavisinde de kullanılmaktadır [53].

Şubat'ın geleneksel üretim yönteminde deve sütü çiğ olarak kullanılırken, süt işletmelerinde süt pastörize/sterilize edilmektedir. Türkmenistan'da da "chal” olarak bilinen Şubat, deve sütüne maya ilave edilerek deri, ahşap veya özel seramik kaplarda 1-3 gün fermentasyona birakılmasıyla elde edilmekte ve genellikle yazın tüketilmektedir. Şubat içeceği yaklaşık 3 ay boyunca muhafaza edilebilmektedir. İç pazarı için Şubat sıvı halde piyasaya sunulurken ihracat için içecek kurutularak toz haline getirilmektedir.

Şubat'ın Kımız'dan farkı yalnızca kullanılan hammadde olmayıp üretimde çalkalama işleminin de yapılmamasıdır. Mayalanmış deve sütü fermentasyon süresince yalnızca oval şeklinde karıştırılmaktadır. Doğal Şubat üretimi yanı sıra ülkede deve sütünden Balkaymak ve biyo-yoğurt gibi süt ürünleri de yapılmaktadır. Deve sütüne inek sütü ya da keçi sütü karıştırıldığında ise "Katık" olarak bilinen bir diğer geleneksel fermente süt ürünü elde edilmektedir.

\subsection{Kurut}

Kurut; kurutmak kökünden gelen Türkçe bir sözcüktür [54, 55]. Kazakistan'da, Özbekistan'da, Türkmenistan'da, Kırgızistan'da ve Tacikistan'da “Kurt” (Қурт), Moğolistan'da "Aaruul”, İran'da “Kashk”, Afganistan'da “Quroot”, Lübnan'da “Kişk”, Irak’ta “Kuşuk”, Suriye'de “Jub-Jub” Arabistan'da ise "Jameed" olarak adlandırılırken [56-58] Türkiye'nin bazı bölgelerinde (Bolu, Van, Ordu, Burdur, Erzurum) de üretilmekte ve "Keş", "Keşük", "Keşk", "Kis", "Çökelek" veya "Kurt" olarak bilinmektedir [59, 60]. Genellikle Kurut'un üretilmesi için inek, keçi veya koyun sütü kullanılmaktadır. Fakat Moğolistan'da ve Başkurdistan'da kısrak sütünden, Ermenistan'da manda sütünden, Afganistan ve Kırgızistan'da deve sütünden de üretimi gerçekleştirilmektedir.

Geleneksel yöntemle Kurut üretimi: Ev yoğurdu bez torbalara aktarılarak 24 saat boyunca süzdürülmekte, daha sonra tuzlandırılıp karıştırılmakta, ardından elde edilen karışıma yuvarlak veya silindirik şekiller verilmektedir. Taze Kurutlar 2-3 gün karanlık bir yerde, ardından 3-5 gün boyunca güneşin altında ve son olarak 2-3 ay tekrar karanlık bir ortamda kurutulduktan sonra tüketime hazır hale gelmektedir. Kurutlar aynı koşullarda nerdeyse 3 yıla kadar muhafaza edilebilmektedir. Ülkenin yerel pazarlarında Kurutlar tüketicinin tercihine göre taze veya kurutulmuş şeklinde satılmaktadır. Kurut genellikle sütün bol olduğu dönemlerde (yazın) küçük aileler tarafından kendi ihtiyaçlarını karşılamak amacı ile yapılmaktadır. Ev şartlarında üretilmesinin yanı sıra Kazakistan'da bazı süt işletmelerinde de Kurut üretilip vakumla ambalajlanarak satışa sunulmaktadır.

Tadı ekşimsi, sulandırıldığında yoğurda benzer, koyu kıvamına sahip olan Kurut Kazakistan'da olduğu şekliyle atıştırmalık olarak tüketilirken, ülkenin bazı yörelerinde ve diğer ülkelerde rendelenerek küçük parçalar halinde çorba, mantı, makarna ve bazı yöresel yemeklerde de kullanılmaktadır [61]. 


\section{SONUÇ}

Kazakistan Cumhuriyetinin ekonomisi metalürji, madencilik, tarım ve hayvancılığa dayalıdır. Orta Asya Türk Cumhuriyetleri arasında en büyük tarımsal potansiyele sahip bir ülke olup ekilebilir arazi ve meralardan oluşan geniş bir tarım alanı ile dünya sıralamasında 6. sıradadır. Süt hayvancılığı ve süt endüstrisi ülkenin tarımsal sanayi kompleksinin en önemli alt sistemlerinden biridir. Ancak, ülke tarımsal üretimin gelişimi için yüksek doğal ve iklimsel potansiyele sahip olmasına rağmen, süt ürünlerinin üretimi ve tüketimi istenilen düzeyde değildir. Süt sektörünün gelişmesini önleyen en büyük iki doğal faktörü; geniş toprak kaynaklarını önemli kısmının tundra, bozkır veya çöl olduğu için ekim için kullanılmaması ve çok sayıda terkedilmiş tarım arazilerinin var olması olarak rapor edilmektedir. Ülkede 2018 yılında elde edilen toplam süt miktarının \%38.1'i sanayiye aktarılabilmiş ve toplam 535.5 bin ton içme sütü ve krema üretilebilmiştir. Süt ve süt ürünleri işletmelerin kaliteli sütlere ulaşabilmesi için çiftçilere çeşitli süt üretimi ile ilgili eğitimlerin verilmesi, işletmelerin ise yeni teknolojilerle desteklenmesi gerekmektedir. Geleneksel süt ürünleri olan Kımız, Şubat ve Kurut Kazakistan'ın ulusal ürünleri ve yerel markalarıdır. Bununla birlikte, bu ürünlerin üretimini arttırmak için ve dünya çapında yaygınlaşması için çeşitli çalışmalar sürdürülmektedir. Uzmanlara göre, kısrak ve deve yetiştiriciliği Kazakistan'da hayvancılığın önde gelen alanlarından biri haline gelebilir. Bu bağlamda geleneksel ürünlerin dış pazarlarda ülkenin markası olma potansiyeli yüksektir.

\section{KAYNAKLAR}

[1] Anonymous, 2019a. Kazakistan Hakkında Genel Bilgiler. Erişim tarihi: 26.03.2020. https://www.ipekyoluasya.org/kazakistan-hakkinda-genel-bilgiler/.

[2] Anonymous, 2020a. Sputnik Kazakhstan. Численность населения Казахстана превысила 18,6 миллиона человек. Erişim tarihi: 26.03.2020. https://ru.sputnik.kz/society/20200215/12848894/kazakhstan-naseleniyechislennost.html.

[3] Liang Y, Zhen L, Zhang C, ve Hu Y, 2020a. Consumption of products of livestock resources in Kazakhstan: Characteristics and influencing factors. Environmental Development, 34: 1-8.

[4] Liang Y, Zhen L, Hu Y, Yan H, ve Zhang C, 2020b. Analysis of the food consumption mode and its influencing factors in Kazakhstan. Journal of Resources and Ecology, 11(1): 121-127.

[5] Timor A N, Bayramli G, ve Kapan K, 2018. Geçmişten günümüze Kazakistan'da tarım faaliyetleri. Igdir University Journal of Social Sciences, (15): 233-255.

[6] NORDEA, 2020. Kazakhstan: Economic and Political Overview. The economic context of Kazakhstan. Erişim tarihi: 17.05.2020. https://www.nordeatrade.com/fi/explore-new-market/kazakhstan/economical-context.

[7] Anonymous, 2020b. Kazportal.kz. Agriculture in Kazakhstan (Сельское хозяйство в Казахстане). Erişim tarihi: 15.06.2020. https://www.kazportal.kz/selskoe-hozyaystvo-v-kazahstane/.

[8] KazAgroExpert. Сельское Хозяйство В Казахстане - Климат, Развитие Отрасли, Характеристики. 2020. Erişim tarihi: 15.06.2020. https://agroexpert.kz/articles/info/selskoe-hozyaistvo.

[9] Chemirbayeva M B, 2018. Diversification of the food industry of Kazakhstan in the conditions of globalization. International Relations and International Law Journal, 3(83): 88-101.

[10] Birjanova A, 2014. Kazakistan Cumhuriyeti'nde gıda endüstrisinin mevcut durumu. (Современное Состояние Пищевой Промышленности в Республике Казахстан). Ivan Kushnir Ekonomi ve Hukuk Enstitüsü. Uluslararas1 
Ekonomik Forumu (Институт Экономики и Права Ивана Кушнира. Международный Экономический Форум). Erişim tarihi: 01.05.2020. http://be5.biz/ekonomika1/r2014/2345.htm.

[11] Temerbayeva M, 2019. Dairy industry of Kazakhstan: current status and development prospects. (Молочная промышленность Казахстана: современное состояние и перспективы развития наилучших доступных технологий специализированных продуктов питания). Павлодарский государственный университет имени С.Торайгырова, 75-79.

[12] Anonymous, 2019b. Капитал. Центр Деловой Информации. Производство молока увеличилось на 8\%. Erişim tarihi: 10.05.2020. https://kapital.kz/economic/82360/proizvodstvo-moloka-uvelichilos-na-8.html.

[13] Davleyev A, 2019. FOODINDUSTRY.KZ. Треугольник устойчивости молочной отрасли: поголовье - надой - производство. Erişim tarihi: 10.06.2020. https://foodindustry.kz/treugolnik-ustojchivosti-molochnoj-otraslipogolove-nadoj-proizvodstvo/.

[14]EnergyProm, 2020а. Молоко и мясо: В Казахстане более 8 миллионов голов КРС, две трети из которых относятся к молочному скоту, и треть - к мясному. Непосредственно коров в стране уже 3,8 миллиона. Erişim tarihi: 25.06.2020. http://www.energyprom.kz/ru/a/monitoring/moloko-i-myaso-v-kazahstane-bolee-8millionov-golov-krs-dve-treti-iz-kotoryh-otnosyatsya-k-molochnomu-skotu-i-tret-k-myasnomuneposredstvenno-korov-v-strane-uzhe-38-milliona.

[15] EnergyProm, 2019b. Животноводы страны бьют рекорды: Поголовье КРС выросло на 6\% за год, птицы сразу на 11\%. Валовый выпуск продукции животноводства перевалил за 2 триллиона тенге. Erişim tarihi: 25.06.2020. http://www.energyprom.kz/ru/a/analytics/zhivotnovody-strany-byut-rekordy-pogolove-krs-vyroslona-6-za-god-pticy-srazu-na-11-valovyj-vypusk-produkcii-zhivotnovodstva-perevalil-za-2-trilliona-tenge.

[16] Sizdıkova J, Kekcebayev E, Jakupova G, 2020. Маркетинговое исследование: сельское хозяйство Казахстана. Erişim tarihi: 01.12.2020. http://marketingcenter.kz/2017/03-07-kazakhstan-selskoe-khoziaistvo.html.

[17] Van Engelen A, 2011. Dairy development in Kazakhstan. Food and Agriculture Organization of the United Nations, Rome.

[18]USK, 2019. Ulusal Süt Konseyi. 2019 Süt Raporu Dünya ve Türkiye'de Süt Sektör İstatistikleri. s. 92.

[19] KCUEBİK, 2019. Kazakistan Cumhuriyeti Ulusal Ekonomi Bakanlığı İstatistik Komitesi. Süt ve Süt Ürünleri Üretim Miktarları 2019. Комитет по статистике Министерства национальной экономики Республики Казахстан (КС МНЭ РК). Erişim tarihi: 25.06.2020. https://kapital.kz/economic/82360/proizvodstvo-molokauvelichilos-na-8.html.

[20] DairyNews, 2020b. DairyNews. Молочное скотоводство в Республике Казахстан. Erişim tarihi: 26.05.2020. https://www.dairynews.ru/news/molochnoe-skotovodstvo-v-respublike-kazakhstan.html.

[21] Tukusheva A, 2019. Inform Бюро. Почему Казахстан в 2020 году столкнётся с молочным кризисом. Erişim tarihi: 10.05.2020. https://informburo.kz/stati/pochemu-kazahstan-v-2020-godu-stolknyotsya-s-molochnymkrizisom.html.

[22] Kovalev G, 2020. Kursiv.kz. В каком направлении будет развиваться молочное производство Казахстана. Erişim tarihi: 30.06.2020. https://kursiv.kz/news/biznes/2020-01/v-kakom-napravlenii-budet-razvivatsyamolochnoe-proizvodstvo-kazakhstana. 
[23] Pokidayev D, 2019. Курсив. В следующем году молочная отрасль Казахстана столкнется с дефицитом сырья. Erişim tarihi: 10.05.2020. https://kursiv.kz/news/vlast-i-biznes/2019-04/v-sleduyuschem-godumolochnaya-otrasl-kazakhstana-stolknetsya-s.

[24] DairyNews. 2020a. DairyNews. Цены на молочные продукты в Казахстане выросли на 7\%. Erişim tarihi: 10.05.2020. https://www.dairynews.ru/news/tseny-na-molochnye-produkty-v-kazakhstane-vyrosli-.html.

[25] ATAMEKEN, 2017. Отчет по результатам исследования. Переработка молока и производство сыра в Республике Казахстан. Almaty. s. 1-63.

[26] EnergyProm, 2019а. КС МНЭ РК. Выпуск молока и сливок в Казахстане увеличился на 11\%. Erişim tarihi: 10.05.2020. https://24.kz/ru/news/economyc/item/297157-vypusk-moloka-i-slivok-v-kazakhstane-uvelichilsyana-11.

[27] Anonymous, 2020c. Производство молока и сливок в РК выросло на 1\% за год. Erişim tarihi: 30.06.2020. https://inbusiness.kz/ru/last/proizvodstvo-moloka-i-slivok-v-rk-vyroslo-na-1-za-god.

[28] EnergyProm, 2019. Kursiv. В Казахстане Дорожают Молочные Продукты. Erişim tarihi: 20.06.2020. https://kursiv.kz/news/kompanii-i-rynki/2019-11/v-kazakhstane-dorozhayut-molochnye-produkty.

[29] FoodMaster, 2020a. Food Master. Пальма первенства. Erişim tarihi: 30.06.2020. https://foodmaster.kz/palmapervenstva/.

[30] Malysheva O, 2015. 9 фактов о производстве «живого» йогурта в Казахстане, которые вас могут удивить. Erişim tarihi: 30.06.2020. https://yvision.kz/post/464286.

[31]FoodMaster, 2020b. Dairy Products of Food Master. Erişim tarihi: 30.06.2020. https://foodmaster.kz/catalog/\#president-ru-ru.

[32] EnergyProm, 2020b. При общем уровне инфляции в 6,7\% сливочное масло выросло в цене более чем на 16\% за год. Erişim tarihi: 30.06.2020. http://www.energyprom.kz/ru/a/monitoring/pri-obshem-urovne-inflyaciiv-67-slivochnoe-maslo-vyroslo-v-cene-bolee-chem-na-16-za-god.

[33] InBusiness, 2018. За последние 3 года производство мороженого в Казахстане выросло на 7,5\%. Erişim tarihi: 21.06.2020. https://inbusiness.kz/ru/last/za-poslednie-3-goda-proizvodstvo-morozhenogo-v-kazahstane-v.

[34] Kudryashova O, 2019. Как Казахстанское мороженое Bahroma завоевало экспортные рынки. Erişim tarihi. https://kursiv.kz/news/kompanii/2019-05/kak-kazakhstanskoe-morozhenoe-bahroma-zavoevalo-eksportnyerynki.

[35] Kurnosova S, 2015. Сделано в Казахстане. мороженое из шубата и кумыса в Шымкенте делают только из местных продуктов. Erişim tarihi: 21.06.2020. https://www.inform.kz/ru/sdelano-v-kazahstane-morozhenoe-izshubata-i-kumysa-v-shymkente-delayut-tol-ko-iz-mestnyh-produktov_a2799668.

[36] Erlanulı О, 2019. Мороженое из кумыса производят в ВКО. Erişim tarihi: 20.06.2020. https://www.inform.kz/ru/morozhenoe-iz-kumysa-proizvodyat-v-vko_a3596685.

[37] Kantureeva G, Defrancesco E, Alibekov R, Urazbayeva K, ve Efimova I, 2018. New trends in the identification of the traditional food products of Kazakhstan. News of the Academy of Sciences of the Republic of KazakhstanSeries Chemistry and Technology, 5(431): 6-12. 
[38] Tegin R A A ve Gönülalan Z, 2014. Bütün yönleriyle doğal fermente ürün, kımız. All Aspects of Koumiss, the Natural Fermented Product. MANAS Journal of Engineering, 2(1): 23-34.

[39] Sidorenko N, 2016. Парное Кобылье Молоко - Полезные Свойства Впрок Не Запасёшь. Erişim tarihi: 25.06.2020. https://informburo.kz/stati/parnoe-kobyle-moloko-poleznye-svoystva-vprok-ne-zapasyosh.html.

[40] Meyrambekov G, 2019. Saumal на Amazon: кобылье молоко из Казахстана покоряет Америку. Erişim tarihi. https://www.youtube.com/watch?v=e9gu3TWcBqc; https://forbes.kz/made_in_kz/saumal_na_amazon_kobyile_moloko_iz_kazahstana_pokoryaet_ameriku/.

[41] Buyanov S, 2015. Forbes Kazakhstan. Как Производить Казахский Кумыс по Немецкой Технологии. Erişim tarihi: 25.06.2020.

https://forbes.kz//process/businessmen/kak_proizvodit_kazahskiy_kumyis_po_nemetskoy_tehnologii/.

[42] Wszolek M, Kupiec-Teahan B, Guldager H S, ve Tamime A Y, 2006. Production of kefir, koumiss and other related products. Fermented milks, 174-216.

[43] Malacarne M, Martuzzi F, Summer A, ve Mariani P, 2002. Protein and fat composition of mare's milk: some nutritional remarks with reference to human and cow's milk. International Dairy Journal, 12(11): 869-877.

[44] Baubekova A, Akhmetsadykova S, Kondybayev A, Faye B, ve Konuspayeva G, 2018. Volatile organic compounds profile of Lactobacillus casei and Streptococcus thermophilus in fermented mare milk of Kazakhstan. International Journal of Biology and Chemistry, 11(2): 28-35.

[45] Hasenova В А, 2014. Производство товарного кумыса и перспектива его развития. Научнопроизводственный журнал "Наука", 13-15.

[46] Küçükçetin A, 2003. Kısrak sütü ve membran teknolojileri kullanılarak kısrak sütüne benzetilmiş inek sütünden yapılan kımızın özellikleri üzerine araştırmalar. Akdeniz Üniversitesi Fen Bilimleri Enstitüsü Gıda Mühendisliği Anabilim Dalı.

[47] Kınık Ö, Akalın S, ve Gönç S, 2000. Kımız üretimi ve özellikleri üzerinde bir araştırma. Gıda, 25(5): 379-384.

[48] Topuz O K, 2005. Farklı starter kültürler ve geleneksel kımız mayası ile üretilen kımızların özellikleri üzerine araştırmalar. Akdeniz Üniversitesi Fen Bilimleri Enstitüsü Gıda Mühendisliği Anabilim Dalı.

[49] Yılmaz L, Kurdal E, 2002. Eskimeyen bir süt içkisi: Kımız. Gıda ve Yem Bilimi Teknolojisi Dergisi, (1): 43-47.

[50] Jukoven O, 2018. Kazinform. 7 видов кумыса производят на ферме в Северном Казахстане. Erişim tarihi: 25.06.2020.https://www.inform.kz/ru/7-vidov-kumysa-proizvodyat-na-ferme-v-severnom-kazahstane_a3313283.

[51] İskakov A J, 2010. Сельское хозяйство Республики Казахстан: вчера и сегодня. Вестник КазНУ (Scientific Articles of Kazakhstan). Erişim tarihi: 15.06.2020. https://articlekz.com/article/8087.

[52] Akhmetsadykova S, Baubekova A, Konuspayeva G, Akhmetsadykov N, ve Loiseau G, 2014. Microflora identification of fresh and fermented camel milk from Kazakhstan. Emirates Journal of Food and Agriculture, 26(4): 327-332.

[53] Konuspayeva G, Faye B, Loiseau G, ve Levieux D, 2007. Lactoferrin and immunoglobulin contents in camel's milk (Camelus bactrianus, Camelus dromedarius, and hybrids) from Kazakhstan. Journal of Dairy Science. Official Publication of the American Dairy Science Association, 90(1): 38-46. 
[54] Patır B ve Ateş G, (2002). Kurut'un mikrobiyolojik ve kimyasal bazı nitelikleri üzerine araştırmalar. Turkish Journal of Veterinary and Animal Sciences, 26(4): 785-792.

[55] Ispirli $\mathrm{H}$ ve Dertli E, 2018. Isolation and characterisation of lactic acid bacteria from traditional Koumiss and Kurut. International Journal of Food Properties, 20(3): 2441-2449.

[56] Omaralieva A, Amanzholov S, Bekturganova A, Yesirkep G, Turekhanova G, Kurmangalieva D, ve Mashanova N, 2016. Mineral composition of Kazakh national milk product: Kurt. Research Journal of Pharmaceutical, Biological and Chemical Sciences, 7(6): 1968-1972.

[57] Golestan L, Seyedyousefi L, Kaboosi H, ve Hamed S, 2016. Effect of Mentha spicata L. and Mentha aquatica L. essential oils on the microbiological properties of fermented dairy product, Kashk. International Journal of Food Science and Technology, (51): 581-587.

[58] Say D, Soltani M, ve Güzeler N, 2015. Kurutulmuş yoğurtlar: Kurut ve Kashk. Pamukkale Universitesi Mühendislik Bilimleri Dergisi, 21(9): 428-432.

[59] Kırdar S S, Kursun Yurdakul Ö, Kalıt S, ve Tudor Kalıt M, 2018. Microbiological changes throughout ripening of Keş cheese. Journal of Central European Agriculture, 17(1): 61-71.

[60] Yaman H ve Coskun H, 2017. Optimization of production technology of Kes for Pasta. Indian Journal of Dairy Science, 70(2): 167-177.

[61] Çakır İ, Coşkun H, Akoğlu İ T, İşleyen M F, Kıralan M, ve Bayrak A, 2009. Introducing a traditional dairy product Keş: chemical, microbiological, and sensorial properties and fatty acid composition. Journal of Food, Agriculture \& Environment, 7(3\&4): 116-119. 